\title{
Nature of Price Adjustment and Market Integration among Stages in Cassava Value Addition Chain in Southern Nigeria
}

\author{
${ }^{1}$ Sunday B. Akpan, ${ }^{2}$ Glory E. Emmanuel and ${ }^{1}$ Inimfon V. Patrick \\ ${ }^{I}$ Department of Agricultural Economics and Extension, Akwa Ibom State University, Nigeria \\ ${ }^{2}$ Department of Agricultural Economics and Extension, University of Uyo, Nigeria
}

Article history

Received: 27-05-2015

Revised: $14-09-2015$

Accepted: 05-10-2015

Corresponding Author:

Sunday B. Akpan

Department of Agricultural

Economics and Extension, Akwa

Ibom State University, Nigeria

E-mail: brownsonakpan10@gmail.com

\section{Introduction}

Recent researches have focused on the relationship between prices of agricultural commodities either along or across food chains (Vavra and Goodwin, 2005; Akpan et al., 2014). Such study on price transmission and the nature of price adjustment is imperative in understanding agricultural market structure and the role of market agents. For instance, asymmetric adjustment in the transmission of prices at various levels of the food marketing system has being of considerable empirical interest to agricultural economists for decades. By definition, asymmetry price transmission refers to pricing phenomenon occurring when the downstream prices react in a different manner to upstream price changes. It implies that, there is an unreciprocal relationship between rise and fall of commodity prices at various stages in the marketing chain. A finding on asymmetric price transmission may allow a researcher to make some inferences about the behaviour of agents in the market, particularly as their actions impact on links across different market levels (Goodwin and Schroeder, 1991). Vavra and Goodwin (2005) noted that, the speed with which markets adjust to shocks is determined by actions of market agents who are involved in the transactions that link market levels; i.e., wholesalers, distributors, processors, retailing firms and the like. Peltzman (2000) also argues that asymmetric price transmission is the rule, rather than the exception and concludes that, since asymmetric price transmission is prevalent in majority of producer and consumer markets, standard economic theory that does not account for this situation must be incorrect. Similarly, Meyer and von Cramon-Taubadel (2004) observed that a possible implication of asymmetric price transmission is that consumers are not benefiting from price reduction at the producers' level, or producers might not benefit from price increase at the 
retail level. Thus, under asymmetric price transmission, the distribution of agents' welfare across levels of market chain following shocks or government interventions will be altered relative to the case of symmetric price transmission. On the other hand, symmetric price adjustment has being noted to help optimize resource use; increase farm incomes; signal the degree of competitiveness, widen commodity markets and encourage value addition as well as create employment (Sexton et al., 1991; Acquah and Rebecca, 2012; Akpan et al., 2014).

Based on the above premise, it is important to study price transmission of agricultural commodity on the assumption of symmetric and asymmetric adjustments in the long run. This is why this study provided answer to the nature of price adjustment between price of cassava (source product) in the rural area and its derivatives (garri, fufu, chip, starch and flour) in urban market on the assumption of symmetric and asymmetric adjustment of the source price in the long run.

Cassava (Manihot esculenta crantz) is a starchy tuberous perennial woody shrub, widely consumed in Nigeria (IITA, 2009). It is one of the major crop components in the food sufficiency initiative programme of the federal Government of Nigeria. Cassava is rarely consumed raw; it is often converted to several useful secondary products or derivatives. For instance, garri, fufu, cassava chips, cassava starch and cassava flour are popular cassava derivatives in Nigeria. Garri is made from fried granule of processed cassava and often enriched with palm oil. It is the most widely traded, processed cassava derivatives in Nigeria. Fufu is a fermented cassava tuber that is usually stirred into a dough-like consistency and often used as a complement to variety of soups. Cassava chips are unfermented partial boiled product of cassava tubers, cut into various sizes and often served with coconut, soup or specially prepared sauce. Also, cassava flour is made from unfermented cassava pieces that have been dried, crushed and blended. It is an additive to bakery industry in Nigeria.

Hence, given the versatility nature of cassava industry in the country, there is an overwhelming need to understand the true relationship between price of raw cassava and it derivatives in the country. The benefits derivable from Government intervention in this sub sector could be stock pile within the marketing chain or concentrated on some agents and thus depriving the intended beneficiaries. Hence, there are needs to understand the long run behavior of price adjustment in this important crop sub sector in the country. The findings will give farmers first-hand information regarding competiveness, incentive for value addition and priority areas for investment in cassava production and processing in the country.
Policy makers will have basic information concerning price movement in this sub sector. Therefore, the study specifically determines the presence of market integration and examines the nature of price adjustment of raw cassava in reaction to price change in its derivatives in the study area.

\section{Review of Related Literature in Nigeria}

Few studies have delved into issues related to cassava market price transmission in Nigeria. For instance, Ojiako and Ezedinma (2007) examined price transmission between supply and demand markets for cassava-based products in Enugu, Eastern region of Nigeria. Results revealed that the rural and urban markets of yellow and white garri were co-integrated. The symmetric error correction model did not, however revealed any significant causality linked between the peripheral and central markets; thus suggesting that there were no clear trends in price leadership between markets. Also, Ibana et al. (2009) studied the price transmission and market integration of cassava products using time series analysis in Nigeria. Results showed that, the market for all products were integrated except for cassava chips in Benue state, white garri in Nasarawa state, yellow garri in Benue state and yellow garri in Edo state. Further results indicated that, price transmission elasticity ranges from 0.434 to 1.00 ; indicating approximately full transmission in some cases. Also, the symmetric price adjustment speed ranges from 11.46 to $47.15 \%$, implying that the speed with which cassava product prices are spatially transmitted between locations was generally low. In a similar manner, Ojiako et al. (2012) studied the interaction between prices of fermented cassava flour in urban and rural supply markets in Nigeria. The result showed that, the pair of price was co-integrated. The Granger causality runs one-way from the rural to the urban market, without a feedback loop. Also, the impulse response analysis revealed that the rural price was more responsive to shock emanating from the rural market. Furthermore, Ojiako et al. (2013) investigated the interaction between Urban and rural market prices of garri in Nigeria. The Granger causality runs one-way from the rural to urban market, without a feedback loop. The impulse response analysis showed that the rural price was more responsive to shock emanating from the urban Market. Recently, Akpan et al. (2014) examined monthly price analysis of cassava derivatives in rural and urban markets in Akwa Ibom State, Nigeria. The cointegration test revealed the presence of co-integration between the rural and urban prices of garri. Weak market integration for fufu was discovered. The 
results of the Error Correction Model (ECM) confirm the existence of the short run market integration.

Available literature have only employed EngleGranger error correction model to investigate the degree of price transmission between markets in Nigeria. Such model might be mis-specified if the error term has asymmetric adjustment in the long run. Also, attempts to measure price transmission or cointegration along food chain have not received prominent attention in the literature in Nigeria. Given the multifaceted roles cassava plays in the self-food sufficiency drive of the federal government and the impact of market integration to the agricultural development, there is need to address these highlighted issues appropriately. As such, a study like this will provide useful literature and serve as a basis to stimulate wider researches on agricultural price transmission in the country.

\section{Research Methodology}

\section{Study Area and Data Source}

The study was carried out in the Southern region of Nigeria. Data were collected in Akwa Ibom State; one of the states in the region. The state was picked for this study because of availability of data. The state also consumed the highest quantity of cassava derivatives and is one of the leading producers of cassava in the country (FMARDR, 2014). Geographically, the state is located between latitudes $4^{\circ} 32^{1}$ and $5^{\circ} 33^{1}$ north and longitudes $7^{\circ} 25^{1}$ and $8^{\circ} 25^{1}$ east. It has a total land area of areas of $7,246 \mathrm{~km}^{2}$. It is bordered on the east by Cross River State, on the west by Rivers State and Abia State and on the South by the Atlantic Ocean. Akwa Ibom State has a population of 3,902,051 (NPC, 2006). The state is basically an agrarian society where crops like cassava, fluted pumpkin, maize, okra and rice among others are cultivated in large quantities. More than $80 \%$ of the state population is involved in agricultural activities, especial the production of fluted pumpkin and cassava.

\section{Source of Data}

Secondary data were used in this study. The data were obtained from the quarterly publications of the Akwa Ibom State Agricultural Development Programme reports (AKADEP). It consisted of the average monthly producer prices (measured in naira per kilogram) of raw cassava and retailed prices of its derivatives (yellow garri, fufu, cassava chips and starch as well as cassava flour). The study covers the period from January 2004 to December 2014. A total of 132 monthly producer prices of cassava in the rural area and average monthly retailed prices of yellow garri, fufu, cassava chips and starch as well as cassava flour in urban market were used in the study.

\section{Analytical Techniques}

The study applied Engle and Granger (1987; Enders and Siklos, 2001) cointegration methodologies to analyze the nature of price movement and adjustment between the rural price of cassava and urban prices of yellow garri, fufu, cassava chips and starch as well as cassava flour in the study area.

\section{Stationarity Analysis of Variables Used in the Study}

\section{Augmented Dickey-Fuller (ADF) Test}

Stationarity in time series is needed to avoid the incidence of spurious regression. It is therefore necessary to convert non- stationary series to stationarity status in order to obtain reliable regression estimates. According to Kennedy (1996), a variable is integrated of order d, $I(d)$, if it has to be differenced $d$ times to become stationary. In order to estimate the cointegration and error correction mechanism of the cassava price with respect to its derivative prices, this study applies the Augmented Dickey- Fuller (ADF) test to first examine the stationarity characteristics of the series. As suggested by Dickey and Fuller (1981), Equation 1 is used to test the stationarity of price series:

$$
\Delta X_{t}=\alpha_{0}+\alpha_{1 t}+\alpha_{2} X_{t-1}+\sum_{i=1}^{k} \delta \Delta X_{t-i}+\varepsilon_{t}
$$

where, ' $X$ ' represents variables to be tested, $\Delta$ represents the first difference operator; $t$ is the time drift; $k$ represents the number of lags used and $\varepsilon$ is the error term, which is assumed to be normally and identically distributed with constant means and variance;' $\alpha$ and $\delta$ are the model bounds. It is a one-sided test whose null hypothesis is $\alpha_{2}=0$ versus the alternative $\alpha_{2}<0$.

\section{Test for Engle Granger Symmetric and Enders and Siklos Asymmetric Co-Integration between Producer Price of Cassava and Retailed Prices of its Derivatives}

The concept of co-integration as developed by Granger (1981) involved the determination of the static or long-run associations among non-stationary time series. If two markets are co-integrated in Engle Granger methodology, then there exists an equilibrium long run relationship with underlying symmetric adjustment between them (Goodwin and Schroeder, 1991; Gonzalez-Rivera and Helfand, 2001; Sexton et al., 1991). The study firstly applied the Engle and Granger two-step technique to examine the co-integration relationship between the price of cassava and its derivatives in the study area. Hence, the time dependent cassava price equation is specified as follows: 


$$
\operatorname{Ln} P_{r t}=\gamma_{0}+\gamma_{1} \sum_{i=1}^{n} \operatorname{Ln} P_{g t}+\varepsilon_{t}
$$

where, $P_{r t}$ and $P_{g t}$ are average monthly producer and retailed prices of cassavaand garri respectively. Possible cointegration between the price of cassava in the rural market and urban prices of garri $\left(P_{g t}\right)$, fufu $\left(P_{f t}\right)$, tapioca $\left(P_{a t}\right)$ and starch $\left(P_{s t}\right)$ and cassava flour $\left(P_{u t}\right)$ were examined through the order of integration of the residual from Equation 2, using a Dicker-Fuller test as below:

$$
\Delta \varepsilon_{t}=\rho \varepsilon_{t-1}+v_{t}
$$

Following the Granger Representation Theorem, we specified the Engle Granger Error Correction Model (ECM) model for the co-integrating series in the study with underlying symmetric adjustment assumption in the long run. The general specification of the Error Correction Model (ECM) specified for the price of cassava in the study area is shown below Equation 4:

$$
\begin{aligned}
& \Delta L n P_{r t}=\gamma_{0}+\gamma_{1} \sum_{i=1}^{n} \Delta L n P_{r t-1} \\
& +\gamma_{2} \sum_{i=1}^{n} \Delta L n P_{g t-i}+\gamma_{3} E C M_{t-1}+U_{t}
\end{aligned}
$$

Variables are as defined previously in Equation 2 and coefficients $\left(\gamma_{3}\right)$ of the $\operatorname{ECM}_{t}\left(-1<\gamma_{3}<0\right)$ measures the deviations from the long-run equilibrium in period $\left.{ }_{t-1}\right)$ in $P_{r t}$. The same relationship was specified for the rest of cassava derivatives (i.e., fufu, starch tapioca and flour). The implicit assumption of symmetric price Adjustment could be problematic if adjustments are asymmetric. Based on this assertion, Enders and Siklos (2001) argued that the test for cointegration could be wrongly specified and thus proposed a tworegime threshold cointegration approach to entail asymmetric adjustment in the cointegration analysis. The proposed model modifies Equation 3, to test for the long run equilibrium that allows for asymmetric adjustment such that:

$$
\Delta \varepsilon_{t}=M_{t} \rho_{1} \varepsilon_{t-1}+\left(1-M_{t}\right) \rho_{2} \varepsilon_{t-1}+\sum_{i=1}^{k} \delta_{i} \Delta \varepsilon_{t-1}+V_{t}
$$

where, $\rho_{2}, \rho_{2}$ and $\delta_{i}$ are coefficients, $\varepsilon_{t}$ is a white noise disturbance, $k$ is the number of lags and $M_{t}$ is an indicator function such that:

$$
M_{t}=\left\{\begin{array}{l}
\text { if } \varepsilon_{t-1} \geq 0 \\
0 \text { if } \varepsilon_{t-1}<0
\end{array}\right.
$$

Hence, model consisting of Equation 3, 5 and 6 is called Threshold Autoregressive (TAR) cointegration model. In the modified version, Enders and Granger (1998; Enders and Siklos, 2001) suggested an alternative threshold based on the change in $\varepsilon_{t-1}$ in the previous period. They proposed a new indicator function $Z_{t}$ such that:

$Z_{t}=\left\{\begin{array}{l}1 \text { if } \Delta \varepsilon_{t-1} \geq 0 \\ 0 \text { if } \Delta \varepsilon_{t-1}<0\end{array}\right.$

Also, model consisting of Equation 3, 5 and 7 is called Momentum-Threshold Autoregressive (M-TAR) cointegration model. The asymmetric cointegration between (rural prices of raw cassava) $P_{r t}$ and (urban prices of yellow garri) $P_{g t}$ using TAR and M-TAR models is determined by testing the null hypothesis of no cointegration:

$$
H_{0}: \rho_{1}=\rho_{2}=0
$$

Enders and Siklos (2001) referred to the F-statistic of this null hypothesis as $\Phi$ and $\Phi^{*}$ in TAR and M-TAR respectively because it has non-standard distribution. They also described Monte Carlo experiments that can be used to test the null hypothesis of no cointegration against the alternative cointegration with threshold (i.e., TAR and M-TAR) adjustment. The asymmetric adjustment is tested when null hypothesis is rejected. Secondly, in the presence of asymmetric cointegration, the null hypothesis of symmetric adjustment can be examined using a standard F-statistics:

$$
H_{0}: \rho_{1}=\rho_{2}
$$

The confirmatory test of asymmetric adjustment of the error correction is indicated when both hypotheses are rejected (i.e., $H_{0}: \rho_{1}=\rho_{2}=0$ and $H_{0}: \rho_{1}=\rho_{2}$ ) when the threshold cointegration is found, the transmission are tested using the threshold error correction model:

$$
\begin{aligned}
& \Delta P_{r t}=\delta_{0}+\theta_{11} M_{t} \varepsilon_{t-1}+\theta_{12}\left(1-M_{t}\right) \varepsilon_{t-1} \sum_{i=1}^{k} \delta_{1 i} \Delta P_{r t-i} \\
& +\sum_{i=1}^{k} \delta_{2 i} \Delta P_{g t-i}+\xi_{1 t}
\end{aligned}
$$

And Equation 9:

$$
\begin{aligned}
& \Delta P_{g t}=\beta_{0}+\theta_{21} M_{t} \varepsilon_{t-1}+\theta_{22}\left(1-M_{t}\right) \varepsilon_{t-1} \sum_{i=1}^{k} \beta_{1 i} \Delta P_{r t-i} \\
& +\sum_{i=1}^{k} \beta_{2 i} \Delta P_{g t-i}+\xi_{2 t}
\end{aligned}
$$


where, $\theta_{11}$ and $\theta_{12}$ represent the speed of adjustment coefficient of $\Delta P_{r t}$ if $P_{r t-1}$ is above and below its long run equilibrium respectively. Also, $\theta_{21}$ and $\theta_{22}$ represent the speed of adjustment coefficients of $\Delta P_{g t}$ of the two regimes respectively. Note, the entire processes were performed for other cassava derivatives specified in this study.

\section{Results and Discussion}

To ascertain the stationarity of variables specified in the model, the standard Augmented Dickey Fuller test was performed. Test statistics for each price variable at level and first difference are presented in Table 1. The result of the ADF unit root test showed that, price series were non-stationary at levels but stationary at first difference for ADF equation without constant and trend. However, the result was mixed for ADF equation that contains constant only. For certainty and high precision of estimates, it was considered that, price variables specified were non stationary at level but stationary at first difference.

Following the result of the unit root tests, equations in the study cannot be analyzed at the level of variables without the risk of obtaining spurious regression. Hence, the result implies that, series should be tested for cointegration.

\section{Descriptive Analysis of Prices used in the Study}

The descriptive statistics of price variables used in the analysis is shown in Table 2. The average prices of
Cassava, yellow Garri, Fufu, chips, Starch and Flourin the study domain were N30.31/kg, N93.05/kg, $\mathrm{N} 74.43 / \mathrm{kg}, \mathrm{N} 106.71 / \mathrm{kg}, \mathrm{N} 138.52 / \mathrm{kg}$ and $\mathrm{N} 175.75 / \mathrm{kg}$ respectively. The coefficients of variability stood at $65.49, \quad 39.53,33.70,36.12, \quad 37.95$ and $66.22 \%$ respectively. These statistics showed that, the rural price of cassava fluctuate higher than the price of its derivatives. The estimated average linear growth rate of prices revealed that, Cassava, yellow Garri, Fufu, chips, Starch and cassava Flour grew at the rate of 6.59, 2.31, $3.88,4.31,15.35$ and $18.85 \%$ respectively.

\section{Engle Granger Co-Integration Model for Price of Cassava and its Derivatives}

The co-integration test result using Engle and Granger two-step technique is presented in the lower portion of Table 3. The order of integration of the residuals generated from the long run equation as specified in Equation 3 for each of the 5 cassava derivatives were evaluated and were found significant at $1 \%$ probability level. Following the Engle-Granger two-step co-integration tests, the null hypothesis of no co-integration was rejected for all 5 cassava derivative equations. The result implies that, there is a long run symmetric equilibrium relationship between the rural price of cassava and urban price of Garri, fufu, chips, starch and cassava flour. The upper parts of Table 3 presents the long run estimates of the cassava equations with respect to the specified derivatives.

Table 1. Result of ADF unit root test for price variables used in the analysis

\begin{tabular}{|c|c|c|c|c|c|c|c|c|}
\hline \multirow[b]{2}{*}{ Logged variables } & \multirow[b]{2}{*}{ Lag } & \multicolumn{2}{|c|}{$\begin{array}{l}\text { ADF test } \\
\text { No constant and trend }\end{array}$} & \multirow[b]{2}{*}{ OT } & \multirow[b]{2}{*}{$\mathrm{Lag}$} & \multicolumn{2}{|c|}{$\begin{array}{l}\text { ADF test } \\
\text { Constant only }\end{array}$} & \multirow[b]{2}{*}{ OT } \\
\hline & & Level & 1st diff. & & & Level & 1st diff. & \\
\hline$P_{r t}$ & 0 & -0.139 & $-17.956^{* *}$ & $1(1)$ & 0 & $-3.596 * *$ & - & $1(0)$ \\
\hline$P_{g t}$ & 0 & -0.250 & $-15.617 * *$ & $1(1)$ & 0 & -3.095 & $-15.592 * *$ & $1(1)$ \\
\hline$P_{f t}^{g t}$ & 0 & -0.135 & $-16.259 * *$ & $1(1)$ & 0 & $-4.504 * *$ & - & $1(0)$ \\
\hline$P_{a t}$ & 0 & -0.218 & $-16.841 * *$ & $1(1)$ & 0 & $-4.709 * *$ & - & $1(0)$ \\
\hline$P_{s t}$ & 0 & -0.642 & $-20.249 * *$ & 1(1) & 0 & $-9.469 * *$ & - & $1(0)$ \\
\hline$P_{u t}$ & 0 & -0.554 & $-17.146^{* *}$ & $1(1)$ & 0 & $-5.301 * *$ & - & $1(0)$ \\
\hline $1 \%$ critical value & & -2.583 & -2.583 & & & $-3.481 * *$ & -3.481 & \\
\hline
\end{tabular}

Note: OT means order of integration. Critical Value (CV) is defined at $1 \%$ significant level for ADF. Asterisks ** represents $1 \%$ significance level. Variables are as defined previously in Equation 2

Table 2. Descriptive statistic of price variables used in the study

\begin{tabular}{|c|c|c|c|c|c|c|}
\hline \multirow[b]{2}{*}{ Parameters } & \multicolumn{6}{|c|}{ Summary of descriptive statistics } \\
\hline & $\begin{array}{l}\text { Rural price of } \\
\text { cassava }(\mathrm{N} / \mathrm{Kg})\end{array}$ & $\begin{array}{l}\text { Urban price of } \\
\text { yellow garri }(\mathrm{N} / \mathrm{Kg})\end{array}$ & $\begin{array}{l}\text { Urban price of } \\
\text { fufu }(\mathrm{N} / \mathrm{Kg})\end{array}$ & $\begin{array}{l}\text { Urban price of } \\
\text { cassava chips }(\mathrm{N} / \mathrm{Kg})\end{array}$ & $\begin{array}{l}\text { Urban price of } \\
\text { starch }(\mathrm{N} / \mathrm{Kg})\end{array}$ & $\begin{array}{l}\text { Urban price of } \\
\text { cassava flour }(\mathrm{N} / \mathrm{Kg})\end{array}$ \\
\hline Mean & 30.3090 & 93.0470 & 74.4310 & 106.7100 & 138.5200 & 175.7500 \\
\hline Median & 21.3400 & 81.3100 & 69.4750 & 93.7400 & 134.3800 & 133.3400 \\
\hline Minimum & 10.3800 & 38.1300 & 32.1600 & 35.4100 & 16.4500 & 20.5300 \\
\hline Maximum & 122.2000 & 192.9000 & 145.5700 & 218.3000 & 308.3300 & 700.0000 \\
\hline Std. deviation & 19.8520 & 36.7810 & 25.0860 & 38.5460 & 52.5660 & 116.4000 \\
\hline Coeff. of Variation & 0.6549 & 0.3953 & 0.3370 & 0.3612 & 0.3795 & 0.6623 \\
\hline Skewness & 1.6608 & 0.8206 & 0.6145 & 0.5169 & 0.6920 & 1.4056 \\
\hline Kurtosis & 2.8528 & -0.1267 & -0.1473 & -0.5658 & 0.9463 & 2.9545 \\
\hline Linear GR (\%) & 6.5870 & 2.3049 & 3.8759 & 4.3128 & 15.3523 & 18.8476 \\
\hline
\end{tabular}

Note: Computed by authors and prices are expressed in nominal terms. Also, 1dollar = N199.05 as of 25/05/015 
Table 3. Long run relationships between rural price of cassava and urban prices of Garri, Fufu, chips, starch and cassava flours

\begin{tabular}{|c|c|c|c|c|c|}
\hline Variable & Garri & Fufu & Chips & Starch & Flour \\
\hline Constant & $-0.63(-1.41)$ & $-0.67(-1.33)$ & $-0.14(-0.26)$ & $1.44(2.71)^{* * *}$ & $0.99(3.43)^{* * *}$ \\
\hline Raw cassava & $0.87(8.71)^{* * *}$ & $0.92(7.84) * * *$ & $0.73(6.47)$ & $0.37(3.40)^{* * *}$ & $0.45(7.81)^{* * *}$ \\
\hline \multicolumn{6}{|c|}{ Diagnostic statistics } \\
\hline $\mathrm{R}^{2}$ & 0.368 & 0.321 & 0.243 & 0.082 & 0.319 \\
\hline F-cal & $75.838 * * *$ & $61.488 * * *$ & $41.915 * * *$ & $11.579 * * *$ & $60.319 * * *$ \\
\hline DW-test & 0.546 & 0.739 & 0.568 & 0.369 & 0.691 \\
\hline Normality test & $57.004 * * *$ & $36.094 * * *$ & $43.144 * * *$ & $27.967 * * *$ & $11.297 * * *$ \\
\hline RESET test & 1.683 & $12.846^{* * *}$ & $11.192 * * *$ & 1.889 & $6.589 * * *$ \\
\hline \multicolumn{6}{|c|}{ ADF unit root test for residuals of above equations } \\
\hline Without const. & $-4.386^{* * *}$ & $-5.485^{* * *}$ & $-4.645 * * *$ & $-3.589 * * *$ & $-5.434 * * *$ \\
\hline With const. & $-4.367 * * *$ & $-5.462 * *$ & $-4.624 * * *$ & $-3.571 * * *$ & $-5.413 * * *$ \\
\hline
\end{tabular}

Note: Values in bracket represent t-values. The asterisk *** represents $1 \%$ significance level. Variables are expressed in logarithm

Table 4. Engle Granger adjustment mechanism (ECM) for price of raw cassava and urban prices of its derivatives

\begin{tabular}{|c|c|c|c|c|c|}
\hline Variable & Garri & Fufu & Chips & Starch & Flour \\
\hline Constant & $0.015(0.63)$ & $0.017(0.70)$ & $0.017(0.69)$ & $0.018(0.78)$ & $0.018(0.76)$ \\
\hline$\Delta \operatorname{Ln} P_{r t-1}$ & $-0.364(-4.23) * * *$ & $-0.368(-4.21)^{* * *}$ & $-0.377(-4.38) * * *$ & $-0.393(-4.64) * * *$ & $-0.392(-4.54) * * *$ \\
\hline$\Delta L n P_{g t}$ & $0.228(1.59)$ & - & - & - & - \\
\hline$\Delta \operatorname{Ln} P_{f t}$ & - & $0.075(0.71)$ & - & - & - \\
\hline$\Delta L n P_{a t}$ & - & - & $0.119(1.27)$ & - & - \\
\hline$\Delta L n P_{s t}$ & - & - & - & $0.165(3.27)^{* * *}$ & - \\
\hline$\Delta \operatorname{Ln} P_{u t}$ & - & - & - & - & $0.114(2.54)^{* *}$ \\
\hline$\Delta L n P_{g t-1}$ & $0.092(0.62)$ & - & - & - & - \\
\hline$\Delta L n P_{f t-1}$ & - & $0.072(0.70)$ & - & - & - \\
\hline$\Delta \operatorname{LnP} P_{a t-1}$ & - & - & $0.013(0.14)$ & - & - \\
\hline$\Delta L n P_{s t-1}^{a t-1}$ & - & - & - & $0.122(2.38)^{* *}$ & - \\
\hline$\Delta L_{n} P_{u t-1}^{\Delta t-1}$ & - & - & - & - & $0.002(0.05)$ \\
\hline $\mathrm{ECM}_{\mathrm{t}-1}$ & $-0.147(-2.43)^{* *}$ & $-0.123(-1.99)^{* *}$ & $-0.114(-2.03)^{* *}$ & $-0.076(-1.69)^{*}$ & $-0.131(-2.17)^{* *}$ \\
\hline \multicolumn{6}{|c|}{ Diagnostic Statistics } \\
\hline $\mathrm{R}^{2}$ & 0.244 & 0.223 & 0.223 & 0.273 & 0.248 \\
\hline F-cal & $10.059 * * *$ & $8.952 * * *$ & $8.948 * * *$ & $11.734 * * *$ & $10.328 * * *$ \\
\hline Normality & $26.277 * * *$ & $25.67 * * *$ & 26.269 & $15.407 * * *$ & $26.942 * * *$ \\
\hline RESET test & 0.365 & 0.866 & 0.769 & 1.539 & 0.226 \\
\hline
\end{tabular}

Note: Values in bracket represent t-values. The asterisks $*, * *$ and $* * *$ represent 10,5 and $1 \%$ significance levels respectively. Variables are as defined previously

\section{Engle Granger (Symmetric) Error Correction Models for Rural Price of Cassava and Urban Price of its Derivatives}

The presence of co-integration between price of cassava and its derivatives demanded the specification of the Error Correction Model. Table 4 contains estimates of ECM generated from Equation 4 for all cassava derivatives. The essence was to determine the speed of adjustment of cassava price to exogenous shock generated by price of garri, chips and starch as well as cassava flour with underlying assumption of symmetric adjustment in the error term.

The result validates the existence of the long-run symmetric equilibrium relationships between the rural price of cassava and urban price of Garri, fufu, chips, starch and flour. The slope coefficient of the error correction termer presents the speed of adjustment and is consistent with the hypothesis of convergence towards the long-run equilibrium once the rural price of cassava equation is shocked. This indicates that, any disequilibrium in the price of cassava in the short run would be corrected in the long run. The significant nature of the Engle-Granger ECM implies that, the urban price of garri, fufu, chips and starch as well as flour will always react to bring stability in the rural price of cassava whenever it experienced significant variation. The Engle -Granger coefficient of the error correction terms implies that, about 14.70, 12.30, 11.40, 7.60 and $13.10 \%$ of symmetric adjustments in the price of cassava take place within every month due to exogenous shock induced by price of garri, fufu, chips, starch and cassava flour respectively. These results confirmed the long and short runs market integration between the rural price of cassava and the urban price of its derivatives with assumption that, the error adjustment is symmetric. Several authors (Shen et al., 2007; Duasa, 2009) have criticized the Engle Granger methodology on the assumption that, the adjustment of the error term in the long run might not follow the fundamental hypothesis. 
Enders and Siklos (Asymmetric) Error Correction Models for Rural Price of Cassava and Urban Price of its Derivatives

By implication, the Engle Granger results discussed above might be wrongly specified if the error terms have underlying asymmetric adjustment. To confirm the true nature of error adjustment, Enders-Siklos asymmetric cointegration test was conducted. The result as presented in Table 5 revealed that the null hypotheses of no asymmetric cointegration and symmetric relationship were rejected for model 2 and 5. This means that, the Engle Granger cointegration wrongly specified the two models. The result connotes that, the long run relationship between the rural price of cassava and urban price of fufu and cassava flour can be describe as asymmetric. However, the results of model 1,3 and 4 were in agreement with the Engle-Granger adjustment procedure in the long run.

Following the presence of asymmetric cointegration between the rural price of cassava and urban prices of fufu and cassava flour, the M-TAR and TAR error correction models were generated to assess their short run dynamics. Table 6 consists of estimates of M-TAR and TAR error correction models for fufu and cassava flour respectively.

The M-TAR error correction model between the price of cassava and fufu revealed that, there is a significant long run asymmetric relationship with the underlying adjustment process been highly asymmetric. The estimated adjustment coefficients are 0.0569 and -0.3567 for the positive and negative values of $\Delta \varepsilon_{t-1}$ respectively. These coefficients imply that, when cassava and fufu price temporarily depart from equilibrium relationship, adjustment back to equilibrium in the long run is more rapid following relative decrease in price of cassava (below long run value) compared to increase in price. Hence, the adjustment is faster when $\Delta \varepsilon_{t-1}$ is negative than when positive. This mechanism is illustrated as thus:

$$
\Delta P_{r t}=K-0.3567\left[P_{r t-1}-0.67+0.92 P_{f t-1}\right] \varepsilon_{t-1}<0
$$

where, " $\mathrm{K}$ " represents the constant and lagged changes in cassava and fufu prices as indicated in Equation 8. The result means that, adjustment back to equilibrium relationship in the long run is faster (about $35.7 \%$ speed adjustment) when temporary departures from equilibrium are caused by relative decrease in cassava price, or increase in fufu price. However, the model did not provide significant evidence for cassava price adjustment relative to fufu price fluctuation when it is above long run linear equilibrium. The result showed that, cassava price has only $5.7 \%$ speed of adjustment back to equilibrium relationship if the temporary departure is caused by relative increase in price of cassava or decrease in the price of fufu.

Table 5. Enders-Siklos asymmetric cointegration test for rural price of cassava and urban price of its derivatives

\begin{tabular}{|c|c|c|c|c|c|c|c|c|}
\hline \multirow[b]{2}{*}{ Variables } & \multicolumn{4}{|c|}{$H_{0}: \rho_{1}=\rho_{2}=0$} & \multicolumn{4}{|c|}{$\mathrm{H}_{0}: \rho_{1}=\rho_{2}$} \\
\hline & $t_{\text {Max }}$. & TAR: $\Phi$ & $\mathrm{K}$ & M-TAR: $\Phi^{*}$ & $t_{\text {Max }}$. & $\mathrm{K}$ & TAR: F-test & M-TAR: F-test \\
\hline Model 1-Garri & -1.4532 & 4.1670 & 1 & 3.5030 & -1.3139 & 1 & 2.1041 & 0.8372 \\
\hline Model 2-Fufu & $-2.0358 *$ & $5.7371 *$ & 1 & $8.0407 *$ & -0.9932 & 1 & 1.5083 & $5.7840 *$ \\
\hline Model 3-Chip & -1.5474 & 4.3859 & 1 & 3.3874 & $-1.8195^{*}$ & 1 & $1.8967 *$ & 0.0007 \\
\hline Model 4-Starch & -0.4802 & 3.0397 & 1 & 2.1932 & -0.6298 & 1 & $2.8432 *$ & 1.1913 \\
\hline Model 5-Flour & -1.7362 & $6.3116^{*}$ & 1 & 5.0268 & -2.2053 & 1 & $2.4221 *$ & 0.0402 \\
\hline
\end{tabular}

Note: Monte Carlos stimulated critical values at $10 \%$ were used. Asterisk * means significant at $10 \%$ level

Table 6. Momentum Threshold Autoregressive (M-TAR) and Threshold Autoregressive (TAR) Asymmetric Error Correction Mechanism for Model 2 and 5

\begin{tabular}{llll}
\hline Variables & M-TAR (Cass. -Fufu) & Variables & TAR (Cass. -Flour) \\
\hline$Z_{t} \varepsilon_{t-1}$ & 0.0569 & $\mathrm{M}_{\mathrm{t}} \varepsilon_{t-1}$ & -0.0964 \\
$(1-Z) \varepsilon_{t-1}$ & $-0.3567 * * *$ & $(1-\mathrm{M}) \varepsilon_{\mathrm{t}-1}$ & $-0.2994^{* *}$ \\
$\Delta P_{r t-1}$ & $-0.5171^{* * *}$ & $\Delta P_{r t-1}$ & $-0.4331^{* * *}$ \\
$\Delta P_{r t-2}$ & -0.1662 & $\Delta P_{r t-2}$ & -0.0608 \\
$\Delta P_{r t-3}$ & -0.0671 & $\Delta P_{r t-3}$ & 0.0072 \\
$\Delta P_{r t-4}$ & -0.0549 & $\Delta P_{r t-4}$ & -0.0518 \\
$\Delta P_{r t-5}$ & -0.1251 & $\Delta P_{r t-5}$ & 0.0038 \\
$\Delta P_{f t-1}$ & -0.1583 & $\Delta P_{u t-1}$ & -0.0078 \\
$\Delta P_{f t-2}$ & -0.0109 & $\Delta P_{u t-2}$ & -0.0203 \\
$\Delta P_{f t-3}$ & -0.1877 & $\Delta P_{u t-3}$ & -0.0225 \\
$\Delta P_{f t-4}$ & -0.1592 & $\Delta P_{u t-4}$ & -0.1409 \\
$\Delta P_{f t-5}$ & -0.0222 & $\Delta P_{u t-5}$ & -0.1169 \\
$\mathrm{R}^{2}$ & 0.457 & & 0.401 \\
F-cal & $7.895 * * *$ & & $6.784 * * *$ \\
RESET test & $8.654^{* * *}$ & & $7.875^{* * *}$
\end{tabular}

Note: Asterisk ${ }^{* *}$ and $* * *$ represent significant level at 10 and $1 \%$ level respectively. EView was used to generate the error correction mechanism 
Similarly, the TAR error correction mechanism between the price of cassava and urban price of cassava flour suggests quick adjustment of cassava price once it falls short of equilibrium position. The model suggests that, about $29.9 \%$ of the last period deviation of cassava price from its equilibrium position will be corrected by cassava price adjustment. This mechanism is shown below:

$$
\Delta P_{r t}=K-0.29994\left[P_{r t-1}-0.99+0.45 P_{u t-1}\right] \varepsilon_{t-1}<0
$$

" $K$ " is as defined previously. The result implies that, when price of cassava and flour temporarily depart from their underling equilibrium relationship, the adjustment back to equilibrium is more rapid and significant following a relative decrease in cassava price or equivalently, an increase in price of fufu. However, the model did not provide significant evidence for cassava price adjustment in the long run relative to flour price variation above its long run value. The implication of the result is that, cassava industry has underlying problems that need to be address in the study area. Issues such as: Seasonality, perishability, poor processing/value addition and short shelf life due to poor storage are worth mentioning.

\section{Discussion of the Long and Short Run Results}

The estimated results revealed that, the rural price of raw cassava and the urban price of its derivatives have long run relationships with varying degrees of error adjustments. The long run market integration coefficient with respect to garri (0.87), fufu (0.92), chips (0.73) and starch (0.37) as well as cassava flour (0.45) is significant but did not converge to the law of one price. These results suggest increasing long run independency in price transmission or relationship between the raw cassava and its derivatives in the study area. For instance, the result has shown that the rural price of cassava and urban price of fufu and cassava flour have asymmetric long run relationship, whereas the price relationship in garri, chip and starch followed symmetric adjustment. The differences in the long run behaviour could be attributed to several issues clouding the cassava industry in the study area. Issues such as: Seasonality, perishability, short shelf life due to poor storage as well as inefficient processing methods is pertinent. The magnitude of these problems causes distortion in cassava-derivative price relationship in the long run. These problems are more pronounced in fufu and flour derivatives and perhaps the issues of asymmetric relationship. The combine result of the short and long run models indicated that, the price of cassava in the rural area does not have a strong deterministic characteristic on urban prices of its derivative in the study area.

\section{Conclusion and Recommendations}

The findings have shown that the rural price of cassava followed symmetric and asymmetric adjustment in the long run with respect to its derivatives. This result portrays the significant influence of externality costs or arbitrage activities in the marketing system of cassava in the study area. These suspected factors though were identified in fufu and cassava flour products; but the price linkage in the rest of the derivative did not converge to the law of one price or instantaneous price change. This result calls for broad policy package that should focus on improving the marketing system and streamlining as well as developing the value addition chain of cassava in the region. Also, production of cassava should be boosted especially during off season, as this will reduce supply shortage. Hence, this paper suggests that, the demand for cassava derivatives is greater than the supply of cassava and that is why price fluctuations in these commodities are not exhibiting strong co-movements in the long run. This result suggests that, potentials in cassava production have not being exploited optimally in study area.

Based on these findings, it is recommended that, governments of the region should bring up programmes to boost cassava production, value addition and competitiveness among farmers in the region. The region authority should provide processing and marketing infrastructures (processing facilities, storage facilities, communication facilities among others) to help reduce externality costs (transportation costs, security levies) associated with cassava marketing chain. There is an overwhelming need to reduce many intermediaries in the marketing of cassava derivatives in the state. The region governments should also establish market information centers and awareness programmes on mass media (such as radio, television and newspaper), to facilitate efficient communication among market agents.

\section{Acknowledgement}

Authors wish to acknowledge the contribution of Mrs. Veronica Brownson in typesetting the final version of this work. We also appreciate the effort of Prof. Edet Joshua Udoh in criticizing the original version of the work.

\section{Author's Contributions}

Sunday B. Akpan: Designed the research work, wrote the introduction and analyzed data collected as well as proof read the manuscript.

Glory E. Emmanuel: Reviewed the empirical literature, developed theoretical framework and proof read the manuscript. 
Inimfon V. Patrick: Reviewed the literature, helped in interpretation of results and proof read the manuscript.

\section{Ethics}

The research was conducted following due scientific procedures. Authors confirmed that this research work is free from all unethical practices.

\section{References}

Acquah, H.D. and R. Owusu, 2012. Spatial market integration and price transmission of selected plantain markets in Ghana. J. Sustainable Dev. Africa, 14: 208-217.

Akpan, S.B., V. Ini-mfon, J. Samuel and J.U. Udoro, 2014. Monthly price analysis of cassava derivatives in rural and urban markets in Akwa Ibom State, Southern Nigeria. J. Agric. Sci., 2: 48-68. DOI: $10.12735 /$ as.v2i1p48

Dickey, D.A. and W.A. Fuller, 1981. Distribution of the estimators for autoregressive time series with a unit root. J. Am. Stat. Assoc., 74: 427-431. DOI: $10.2307 / 2286348$

Duasa, J., 2009. Asymmetric cointegration relationship between real exchange rate and trade variables: The case of Malaysia. Munich Personal RePEc; Archiv. MPRA Paper No. 14535.

Enders, W. and C.W. Granger, 1998. Unit-root tests and asymmetric adjustment with an example using the term structure of interest rates. J. Bus. Economic Stat., 16: 304-311. DOI: $10.1080 / 07350015.1998 .10524769$

Enders, W. and P.L. Siklos, 2001. Cointegration and threshold adjustment. J. Bus. Economic Stat., 19: 166-176. DOI: 10.1198/073500101316970395

Engle, R.F. and C.W.J. Granger, 1987. Co-integration and error correction: Representation, estimation and testing. Econometrica, 49: 251-276. DOI: $10.2307 / 1913236$

FMARDR, 2014. Federal Ministry of Agriculture and Rural Development Reports.

Gonzalez-Rivera, G. and S.M. Helfand, 2001. The extent, pattern and degree of market integration: A multivariate approach for the Brazilian rice market. Am. J. Agric. Econom., 83: 576-592. DOI: $10.1111 / 0002-9092.00179$

Goodwin, B.K. and T.C. Schroeder, 1991. Cointegration tests and spatial price linkages in regional cattle markets. Am. J. Agric. Econom., 73: 452-464. DOI: $10.2307 / 1242730$

Granger, C.W.J., 1981. Some properties of time series data and their use ineconometric model specification. J. Econometr., 16: 121-130.
Ibana, S.E., N.M. Nkang and C. Ezedinma, 2009. Price transmission and market integration: A test of the central market hypothesis of geographical markets for cassava products in Nigeria. Global J. Pure Applied Sci., 15: 3-4.

IITA, 2009. Cassava. IITA official website.

Kennedy, P., 1996. A Guide to Econometrics. 3rd Edn., Blackwell Publishers Inc., Massachusetts.

Meyer, J. and S. Von Cramon-Taubadel, 2004. Asymmetric price transmission: A survey. J. Agric. Econom., 55: 581-611. DOI: $10.1111 / \mathrm{j} .1477-9552.2004 . t b 00116 . \mathrm{x}$

NPC, 2006. Publications. National Population Commission.

Ojiako, I.A., C. Ezedinma, G.N. Asumugha and N.M. Nkang, 2012. Spatial integration and price transmission in selected cassava products' markets in Nigeria: A case of lafun. World Applied Sci. J., 18: 1209-1219. DOI: 10.5829/idosi.wasj.2012.18.09.642

Ojiako, I.A., C. Ezedinma, R.U. Okechukwu and G. N. Asumugha, 2013. Spatial integration and price transmission in selected cassava products' markets in Nigeria: A case of gari. World Applied Sci. J., 22: 1373-1383.

DOI: 10.5829/idosi.wasj.2013.22.09.1036

Ojiakoand, I.A. and C. Ezedinma, 2007. Price transmission between supply and demand markets for cassava-based products: A cointegration analysis for garri in Enugu state, Nigeria. Afr. J. Food Agric. Nutrit. Dev., 7: 1-19.

Peltzman, S., 2000. Prices rise faster than they fall. J. Political Economy, 108: 466-502.

DOI: $10.1086 / 262126$

Sexton, R.J., C.L. Kling and H.F. Carman, 1991. Market integration, efficiency of arbitrage and imperfect competition: Methodology and application to U.S. celery. Am. J. Agric. Econom., 73: 568-580. DOI: $10.2307 / 1242810$

Shen, C.H., C.F. Chen and L.H. Chen, 2007. An empirical study of the asymmetric cointegration relationships among the Chinese stock Markets. Applied Econom., 39: 1433-1445. DOI: $10.1080 / 00036840600606302$

Vavra, P. and B.K. Goodwin, 2005. Analysis of price transmission along the food Chain. OECD Food Agriculture and Fisheries Working Papers, OECD Publishing. 